\title{
EFFECT OF UROTENSIN II ON WATER AND ION FLUXES IN THE INTESTINE, GALLBLADDER AND URINARY BLADDER OF THE FRESHWATER TELEOST, Hoplias malabaricus.
}

\author{
Bernardo Baldisserotto, Roni João Rakoski and \\ Ciro Luiz da Silva Fernandes \\ Departamento de Fisiologia - Centro de Ciências da Saúde \\ UFSM, Santa Maria, RS \\ Olga Martins Mimura \\ Departamento de Fisiologia - Instituto de Biociências \\ USP, São Paulo, SP
}

\section{RESUMO}

O efeito da urotensina II (UII) nos fluxos de água e íons $\left(\mathrm{Na}^{+}, \mathrm{K}^{+}\right.$,

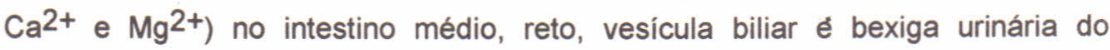
teleósteo dulciaquícola Hoplias malabaricus foi investigado. O fluxo de água em todos os órgãos estudados de $H$. malabaricus é mucosa-serosa (absorção). A UII aumentou o fluxo de água no intestino médio, vesícula biliar e bexiga urinária. $O$ intestino médio, a vesícula biliar e a bexiga urinária também absorvem $\mathrm{Na}+. \mathrm{O}+$ é absorvido no reto e secretado na bexiga urinária. A UII não alterou os fluxos de $\mathrm{Na}^{+}$e $\mathrm{K}^{+}$nas porções estudadas. Todos os órgãos estudados secretaram $\mathrm{Ca}^{2+}$, e a UII reduziu o fluxo deste íon no intestino médio e bexiga urinária. O fluxo de $\mathrm{Ca}^{2+}$ no reto e na vesícula biliar não foi afetado pela UII. Não há nenhum fluxo significativo de $\mathrm{Mg}^{2+}$ nas porções estudadas, e a UIl estimulou a absorção deste ín no intestino médio e bexiga urinária. Este estudo indica que a UII participa do controle de órgãos osmorreguladores de H. malabaricus. Além disso, este trabalho também levanta a possibilidade de que a UII possa estar envolvida na regulação da composição iônica da bile dos peixes, uma vez que este hormônio altera o fluxo de água e $\mathrm{Ca}^{2+}$ na vesícula biliar de $H$. malabaricus. 


\section{ABSTRACT}

The effect of urotensin II (UII) on the flow of water and ions $\left(\mathrm{Na}^{+}, \mathrm{K}^{+}\right.$, $\mathrm{Ca}^{2+}$ and $\mathrm{Mg}^{2+}$ ) in the medium intestine, rectum, gallbladder and urinary bladder of the freshwater teleost Hoplias malabaricus was investigated. The flow of water of all the studied organs of $H$. malabaricus is from mucosa to serosa (absorption). UII increased the flow of water in the medium intestine, gallbladder and urinary bladder. The medium intestine, gallbladder and urinary bladder also absorb $\mathrm{Na}^{+}$. $\mathrm{K}^{+}$is absorbed in the rectum and secreted in the urinary bladder. UII did not affect the flow of $\mathrm{Na}^{+}$and $\mathrm{K}^{+}$in the studied portions. All studied portions secreted $\mathrm{Ca}^{2+}$, and UII reduced the flow of this ion in the medium intestine and urinary bladder. The flow of $\mathrm{Ca}^{2+}$ in the rectum and gallbladder was not altered by UII. There is no significant flow of $\mathrm{Mg}^{2+}$ in the studied portions, and UII stimulated the absorption of this ion in the medium intestine and urinary bladder. This study indicates that UII participates in the control of osmoregulatory organs of $H$. malabaricus. This study also raises the possibility that UII may be involved in the regulation of the composition of the bile of fishes, since it alters water and $\mathrm{Ca}^{2+}$ fluxes in the gallbladder of $H$. malabaricus.

\section{INTRODUCTION}

Urotensin II (UII), a neurohormone produced by the caudal neurosecretory system, has a well defined vasoconstrictor and pressor effect in fishes (Hazon et al., 1993). However, its role in osmoregulation remains unclear. A specific role for UII in freshwater adaptation was suggested, since the effects of this neurohormone on some osmoregulatory organs would led to an increase of plasma ion concentration (Loretz et al., 1981; Baldisserotto, 1991). UII inhibited Clsecretion by the skin of Gillichthys mirabilis (Marshall and Bern, 1981) and opercular membrane of Oreochromis mossambicus (Foskett and Hubbard, 1981; Loretz et al., 1981), change of water, and/or $\mathrm{Na}+$ and $\mathrm{Cl}$ - absorption in the intestine of G. mirabilis (Loretz et al., 1983), O. mossambicus (Mainoya and Bern, 1982, 1984) and Anguilla anguilla (Baldisserotto and Mimura, 1996), and increased diuresis in Anguilla japonica (Chan, 1975). In contrast, UII enhances the 
reabsorption of $\mathrm{Na}^{+}$in the urinary bladder of $\mathrm{G}$. mirabilis (as occurs in seawateradapted specimens) (Loretz and Bern, 1981) and inhibited prolactin secretion (the most important hormone in freshwater adaptation) (Rivas et al., 1986).

In view of the above mentioned results, this study investigated the effects of UII on the flow of water and ions in the intestine, gallbladder and urinary bladder of the freshwater teleost, Hoplias malabaricus, in an attempt to elucidate the role of this neurohormone in fish osmoregulation.

\section{MATERIAL AND METHODS}

Specimens of Hoplias malabaricus (Erythrinidae) (200 - $500 \mathrm{~g}$ fresh weight) of both sexes were captured with nets placed in ponds situated on the campus of the Federal University of Santa Maria (UFSM), Santa Maria, RS, Brazil. Fishes fasted during 3 days, according to Baldisserotto et al. (1990a), prior to experiments. The fishes were killed and the abdominal cavity opened to expose the medium intestine, rectum (names of these portions of the intestine are according to the description of Menin, 1988), gallbladder and urinary bladder. These organs were separated and cleaned with Ringer-bicarbonate solution (in $\mathrm{mM}$ ): $\mathrm{NaCl} 120.0 ; \mathrm{KCl}$ 5.5; $\mathrm{MgSO}_{4} .7 \mathrm{H}_{2} \mathrm{O}$ 1.45; $\mathrm{CaCl}_{2} .2 \mathrm{H}_{2} \mathrm{O} 3.0 ; \mathrm{NaHCO}_{3}$ 10.0; glucose 2.5; adjusted to $\mathrm{pH} 7.0$ with $\mathrm{HCl}$. Non everted sacs of each segment (with a volume of $0.2-0.5 \mathrm{ml}$ of Ringer-bicarbonate solution) were prepared. The sac was blotted, weighed and immersed in $20 \mathrm{ml}$ of aerated Ringer-bicarbonate solution $\left(22^{\circ} \mathrm{C}\right)$ for $1 \mathrm{~h}$. After incubation, the sac was blotted and weighed. The luminal fluid was collected for determination of ions concentrations. Cation concentrations where determined by flame $\left(\mathrm{Na}^{+}\right.$and $\left.\mathrm{K}^{+}\right)$and absorption $\left(\mathrm{Ca}^{2+}\right.$ and $\left.\mathrm{Mg}^{2+}\right)$ spectrophotometry (Zeiss $P M$ QII). The empty sac was blotted and weighed again. The flow of water and ions $\left(\mathrm{Na}^{+}, \mathrm{K}^{+}, \mathrm{Ca}^{2+}\right.$ and $\left.\mathrm{Mg}^{2+}\right)$ were obtained using the equations described by Baldisserotto et al. (1993) and were expressed as $\mu \mathrm{l}$ of water or $\mu \mathrm{Eq}$ of the ion transferred from mucosa to serosa (or serosa to mucosa) as a function of fresh weight of the organ $(\mathrm{g})$ Juring $1 \mathrm{~h}$ ( $\mu \mathrm{l} / \mathrm{g}$ tissue.h or $\mu \mathrm{Eq} / \mathrm{g}$ tissue.h). Sacs were incubated in the presence or absence of UII (Sigma) $\left(2 \times 10^{-8} \mathrm{M}\right)$ on the serosal side. This dose was chosen because it proved effective to change the flow of ions in the intestine of Gillichthys mirabilis (Loretz et al., 1983) and Oreochromis 
mossambicus (Mainoya and Bern, 1982, 1984). All values were expressed as the mean \pm SE. In order to verify the significance of the flow of water and ions, and of the difference between these flows, in the presence or absence of UII, the tStudent test was used. The minimum significant level was $p<0.05$. All test were run on the Microstat program (Ecosoft, Inc.). When flow values were statistically different from zero, positive values indicated a net mucosa-serosa flow (absorption), while negative ones indicated a serosa-mucosa flow (secretion).

\section{RESULTS}

The flow of water in all studied organs of $H$. malabaricus is from mucosa to serosa (absorption). UII increased the flow of water in the medium intestine, gallbladder and urinary bladder. The water flow of the rectum was not affected by this neurohormone. The medium intestine, gallbladder and urinary bladder also absorbed $\mathrm{Na}^{+}$. The flow of this ion was not statistically different from zero in the rectum. Ull did not change the flow of $\mathrm{Na}^{+}$in the studied portions (figure 1). $\mathrm{K}^{+}$is absorbed in the rectum and secreted in the urinary bladder. There was no flux of $\mathrm{K}^{+}$in the medium intestine and gallbladder. Ull did not affect the flow of this ion in the studied portions. All studied portions secreted $\mathrm{Ca}^{2+}$, and the flow of this ion in the medium intestine and the urinary bladder was reduced by UII. The flow of $\mathrm{Ca}^{2+}$ in the rectum and gallbladder was not altered by UII. There was no significant flow of $\mathrm{Mg}^{2+}$ in the studied portions, and UII stimulated the absorption of this ion in the medium intestine and urinary bladder (figure 2).

\section{DISCUSSION}

1 - Medium intestine and rectum: The medium intestine and rectum of $H$. malabaricus absorb water and $\mathrm{Na}^{+}$(only medium intestine) as observed in the intestine of several freshwater-adapted teleosts (Smith et al., 1975; Mainoya, 1982; Nakamura, 1985; Mimura et al., 1987; Baldisserotto et al., 1993; Baldisserotto and Mimura, 1995). 

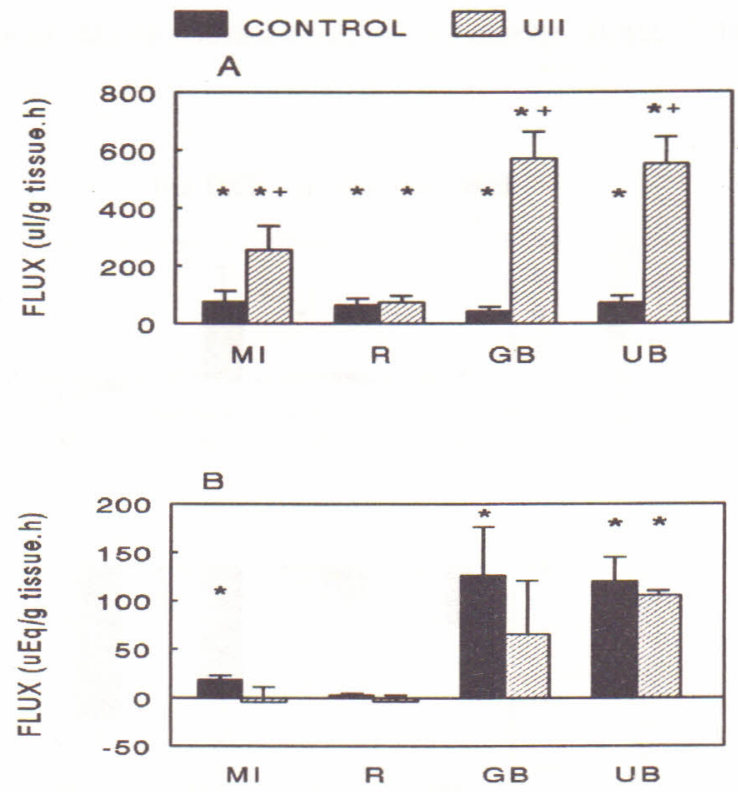

Figure 1 - Effects of UII in the flows of water $(A)$ and $\mathrm{Na}^{+}(\mathrm{B})$ in the medium intestine (MI), rectum (R), gallbladder (GB) and urinary bladder (UB) of Hoplias malabaricus.

Mean flow values significantly different from zero $\quad{ }^{\star} p<0.05$

Mean flow values significantly different from control $+p<0.05$

Measurements of the flow of $\mathrm{K}^{+}$in the intestine of freshwater-adapted teleosts have given conflicting results: this ion was absorbed in the intestine of some species, as $H$. malabaricus (rectum) and C. carpio (medium intestine) (Nakamura, 1985), but in other there was no flow, as S. marmoratus (Baldisserotto et al., 1993), or this ion is secreted, as $P$. scrofa (Baldisserotto and Mimura, 1995). Calcium is secreted by the intestine of $H$. malabaricus, $P$. marggravii (Mimura et al., 1987), and P. scrofa (Baldisserotto and Mimura, 1995). However, transport of $\mathrm{Ca}^{2+}$ was not apparent in the intestine of $C$. carpio (Nakamura, 1985), and this ion was absorbed in the anterior intestine of $S$. marmoratus (Baldisserotto et al., 1993). There was no flow of $\mathrm{Mg}^{2+}$ in the intestine of $H$. malabaricus, as was observed in the intestines of C. carpio (Nakamura, 1985), and S. marmoratus 
(Baldisserotto et al., 1993). However, the intestines of $P$. marggravii (Mimura et al., 1987), and $P$. scrofa secrete this ion (Baldisserotto and Mimura, 1995).
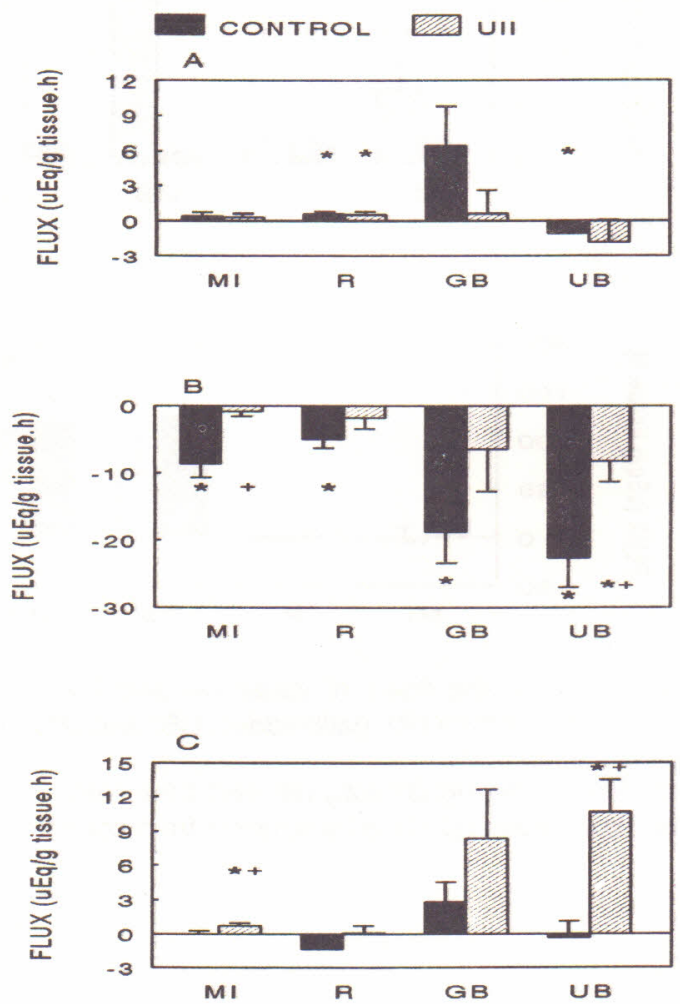

Figure 2 - Effects of UII in the flows of $\mathrm{K}^{+}(\mathrm{A}), \mathrm{Ca}^{2+}(\mathrm{B})$, and $\mathrm{Mg}^{2+}(\mathrm{C})$ in the medium intestine $(\mathrm{MI})$, rectum $(\mathrm{R})$, gallbladder $(\mathrm{GB})$ and urinary bladder (UB) of Hoplias malabaricus.

Mean flow values significantly different from zero $\quad * 0<0.05$

Mean flow values significantly different from control $+p<0.05$

The available information on the flow of ion and water in the intestine of $H$. malabaricus suppc. ${ }^{+}$s the hypothesis that this organ absorbs water and $\mathrm{Na}^{+}$ and excretes $\mathrm{Ca}^{2+}$ in freshwater-adapted teleosts. The transport of $\mathrm{K}^{+}$and $\mathrm{Mg}^{2+}$ in the intestine of freshwater-adapted teleosts seems to vary from species to species. 
UII increased the absorption of water only in the medium intestine and did not change the flow of $\mathrm{Na}^{+}$in the medium intestine and rectum of $\mathrm{H}$. malabaricus. The same dose of UII also increased the absorption of water, $\mathrm{Na}^{+}$ and $\mathrm{Cl}^{-}$in the anterior intestine of $\mathrm{O}$. mossambicus, but only in seawater-adapted fishes (Mainoya and Bern, 1982, 1984), and $\mathrm{Na}^{+}$and $\mathrm{Cl}^{-}$in the posterior intestine of $5 \%$ seawater-adapted Gillichthys mirabilis (Loretz et al., 1983). However, UII decreased the short-circuit current and transepithelial potential difference of the posterior intestine "in vitro" of freshwater-adapted Anguilla anguilla. The reducement of these parameters could be due to a decrease in the absorption of $\mathrm{Na}^{+}$and $\mathrm{Cl}^{-}$by this organ (Baldisserotto and Mimura, 1996). UII inhibited the secretion of $\mathrm{Ca}^{2+}$ and stimulated the absorption of $\mathrm{Mg}^{2+}$ in the medium intestine of $H$. malabaricus, and had no effect on the flow of $\mathrm{K}^{+}$in the intestine of this species. Since the effect of UII on the transport of $\mathrm{K}^{+}, \mathrm{Ca}^{2+}$, and $\mathrm{Mg}^{2+}$ in the intestine was not previously investigated, comparison with other species is not possible. All the above described effects of UII in the intestine of teleosts, with the exception of the increase of water absorption in the medium intestine of $H$. malabaricus, are related to freshwater adaptation.

2 - Gallbladder: Analyses of the gallbladder bile of fasted teleosts demonstrated that the concentrations of $\mathrm{Na}^{+}, \mathrm{K}^{+}, \mathrm{Ca}^{2+}$, and $\mathrm{Mg}^{2+}$ are higher in the gallbladder bile than in the plasma, while the concentration of $\mathrm{Cl}$ - is lower in the gallbladder bile (Hunn, 1972; Baldisserotto et al., 1990b). The levels of $\mathrm{Ca}^{2+}$, $\mathrm{Mg}^{2+}$, and $\mathrm{Cl}^{-}$in the gallbladder bile of fasted $\mathrm{H}$. malabaricus maintain the same pattern. However, the levels of $\mathrm{Na}^{+}$and $\mathrm{K}^{+}$in the gallbladder are not different from plasma levels in this species (Baldisserotto and Mimura, in press). The gallbladder of $H$. malabaricus absorbed water and $\mathrm{Na}^{+}$, as observed in other teleosts (Diamond, 1962; Hirano and Bern, 1972; Baldisserotto and Mimura, 1992). Ca2+ secretion was also detected in the gallbladder of $H$. malabaricus. However, the gallbladder of $S$. marmoratus absorbs this ion and no flow was observed in that of P. scrofa (Baldisserotto and Mimura, 1992). There was no flow of $\mathrm{K}^{+}$and $\mathrm{Mg}^{2+}$ in the gallbladder of $H$. malabaricus, but $\mathrm{K}^{+}$and $\mathrm{Mg}^{2+}$ are absorbed by the gallbladder of $S$. marmoratus and $\mathrm{K}^{+}$secreted by that of $P$. scrofa (Baldisserotto and Mimura, 1992).

UII increased the absorption of water, inhibited the secretion of $\mathrm{Ca}^{2+}$ 
and did not alter the flows of $\mathrm{Na}^{+}, \mathrm{K}^{+}$, and $\mathrm{Mg}^{2+}$ in the gallbladder of $H$. malabaricus. Urophysial extract also stimulated the flows of water (secretion), $\mathrm{K}^{+}$, and $\mathrm{Mg}^{2+}$, inhibited that of $\mathrm{Ca}^{2+}$, and did not change that of $\mathrm{Na}^{+}$in the gallbladder of S. marmoratus (Mimura and Baldisserotto, 1989). Since the reabsorption of water by the gallbladder is essential to concentrate the bile produced by the liver (Diamond, 1962), the effect of UII on the water transport on this organ could be important to increase its capacity to store the bile for a longer period of time. Besides, the fact that UII alters water and $\mathrm{Ca}^{2+}$ fluxes in the gallbladder of $H$. malabaricus also raises the possibility that UII may be involved with the regulation of the composition of the bile of fishes.

3 - Urinary bladder: The urinary bladder of $H$. malabaricus absorbed water and $\mathrm{Na}^{+}$at a similar rate to that of the urinary bladder of freshwater-adapted S. irideus (Fossat and Lahlou, 1977) and Platichthys stellatus (Demarest, 1984). The absorption of $\mathrm{Na}^{+}$by the urinary bladder of freshwater teleosts is important to reduce the quantity lost by the urine (at least $40 \%$ of urinary losses) (Curtis and Wood, 1991), and could be related to $\mathrm{H}^{+}$excretion (Cameron and Wood, 1978). A secretion of $\mathrm{K}^{+}$and $\mathrm{Ca}^{2+}$ was also detected in the urinary bladder of $\mathrm{H}$. malabaricus. The urinary bladder of the seawater-adapted Pseudopleuronectes americanus also secretes $\mathrm{K}^{+}$(Dawson and Frizzell, 1989). To our knowledge there are not available studies related to the flows of $\mathrm{Ca}^{2+}$ and $\mathrm{Mg}^{2+}$ in the urinary bladder of teleosts.

UII increased the permeability of the urinary bladder of $H$. malabaricus to water, since the absorption of water was largely increased. There are no studies related to the effects of UII on water absorption by the urinary bladder, but urophysial extract increased the permeability of water in the urinary bladder of the toad Bufo marinus (Lacanilao, 1969). However, neither injection of this extract nor urophysectomy changed water movement in the urinary bladder of fresh- and seawater-adapted $P$. stellatus (Johnson et al., 1972). UII also increased $\mathrm{Mg}^{2+}$ absorption and reduced $\mathrm{Ca}^{2+}$ secretion in the urinary bladder of $H$. malabaricus. The flows of $\mathrm{Na}^{+}$and $\mathrm{K}^{+}$were not modified by UII. This hormone increased the absorption of $\mathrm{Na}^{+}$in the urinary bladder of seawater-adapted $\mathrm{G}$. mirabilis (Loretz $\mathrm{e}$ Bern, 1981).

It could be argued that the lack of effect of UII on the flow of some ions 
in the studied organs of $H$. malabaricus can be due to the degradation of this neurohormone by peptidases. However, this hypothesis is less probable, since similar experiments with other species also did not use peptidases inhibitors and UII had effect (Loretz et al., 1983; Mainoya and Bern, 1982, 1984; Hazon et al., 1993). In addition, UII was added to the serosal side, and intestinal enzymes are secreted by the mucosal side.

The present study indicates that UII participates in the regulation of osmoregulatory organs of $H$. malabaricus. The stimulation of water absorption in the medium intestine and urinary bladder by this neurohormone could be related to seawater adaptation. However, this species lives only in freshwater (Paiva, 1974) and such effect of UII would increase the need of water excretion by the fish. On the other hand, the inhibition of $\mathrm{Ca}^{2+}$ secretion and the increased absorption of $\mathrm{Mg}^{2+}$ in the medium intestine and urinary bladder seems to be more related to freshwater adaptation. These results and the conflicting UII effects described in another teleosts, mentioned in the introduction, are not sufficient to determine the function of this neurohormone on sea- or freshwater adaptation in teleosts.

\section{ACKNOWLEDGMENTS}

The authors would like to thank Mr. Manassés S. Lima (USP) for his technical assistance on ion analysis and Dr. Mário de la Rue (UFSM) for the critical analysis of this article.

\section{REFERENCES}

Baldisserotto, B. Transnorte de íns no intestino de Anquilla anguilla (Pisces): estudos eletrofisiológicos. Ph.D. thesis, Instituto de Biociências, Universidade de São Paulo, São Paulo, Brazil, 154p, 1991.

Baldisserotto, B. and Mimura, O.M. Transporte de íons e água na vesícula biliar de teleósteos. Abstract XXI Enc. An. Cien. Fisiológicas, Porto Alegre, Brazil, 1992. 
Baldisserotto, B. and Mimura, O.M. Ion and water transport in the gut of the freshwater teleost Prochilodus scrofa. Ciência e Cultura, v. 47,n.1/2, p.83-85, 1995.

Baldisserotto, B. and Mimura, O. M. Changes in the electrophysiological parameters of the posterior intestine of Anguilla Anguilla (pisces) induced by oxytacin, urotensin II and aldasterone. Braz. J. Med. Bial. Res.,v.29, 1996 (in press).

Baldisserotto, B. and Mimura, O.M. Ionic content of the gallbladder bile of the teleost fish Hoplias malabaricus in different digestive phases. Ciência e Cultura, in press.

Baldisserotto, B.; Mimura, O.M.; Farias, A.P.T. and Christensen, F. Effect of luminal pH on gastric motility "in vitro" of Hoplias malabaricus (TELEOSTEI). Bol. Fisiol. Anim. S. Paulo, v.14, p.13-17, 1990a.

Baldisserotto, B.; Mimura, O.M.; Salomão, L.C. Gallbladder bile and plasma ionic

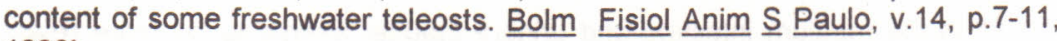
$1990 \mathrm{~b}$.

Baldisserotto, B.; Mimura, O.M. and Salomão, L.C. Effect of pH on ion and water transport in the gut of the freshwater teleost, Synbranchus marmoratus. Ciência e Cultura, v.45, p.396-398, 1993.

Cameron, J.N. and Wood, C.M. Renal function and acid base regulation in two amazonian erythrinid fishes: Hoplias malabaricus, a water breather, and Hoplerythrinus unitaeniatus, a facultative air breather. Can. J. Zool., v.56, p.917-930, 1978.

Chan, D.K.O. Cardiovascular and renal effects of urotensins I and II in the eel, Anguilla rostrata. Gen. Comp. Endocrinol., v.27, p.52-61, 1975.

Curtis, B.J. and Wood, C.M. The function of urinary bladder "in vivo" in the freshwater rainbow trout. J. Exp. Biol., v.155, 567-583, 1991.

Dawson, D.C. and Frizzell, R.A. Mechanism of active $\mathrm{K}^{+}$secretion by flounder urinary bladder. Pfluegers Arch. Eur. J. Physiol., v.414, n.4, p.393-400, 1989.

Demarest, J.R. Ion and water transport by the flounder (Platichthys stellatus) urinary bladder: salinity dependence. Am. J. Physiol., v.246, n.4 part 2, p.F395F401, 1984.

Diamond, J.M. The reabsorptive function of the gall-bladder. J. Physiol., v.161, p.442-473, 1962.

Foskett, J.K. and Hubbard, G.M. Hormonal control of chloride secretion by teleost opercular membrane. Abstract Ann. N. Y. Acad. Sci., v.372, p.643, 1981.

Fossat, B. and Lahlou, B. Osmotic and solute permeabilities of isolated urinary bladder of the trout. Am. J. Physiol., v.233, p.F525-F531, 1977. 
Hazon, N.; Bjenning, C. and Conlon, J.M. Cardiovascular actions of dogfish urotensin II in the dogfish Scyliorhinus canicula. Am. J. Physiol., v.265, p.R573R576, 1993.

Hirano, T. and Bern, H.A. The teleost gall bladder as an osmoregulatory organ. Endocrinol. Japon., v.19, p.41-46, 1972.

Hunn, J.B. Concentrations of some inorganic constituents in gallbladder bile from some freshwater fishes. Copeia, v.4, p.860-861, 1972.

Johnson, D.W.; Hirano, T.; Bern, H.A. and Conte, F.P. Hormonal control of water and sodium movements in the urinary bladder of the starry flounder, Platichthys stellatus. Gen. Comp. Endocrinol., v.19, n.1, p.115-128, 1972.

Lacanilao, F. Teleostean urophysis: stimulation of water movement across the bladder of the toad Bufo marinus. Science, v.163, p.1326-1327, 1969.

Loretz, C. and Bern, H.A. Stimulation of sodium transport across the teleost urinary bladder by urotensin II. Gen. Comp. Endocrinol., v.43, n.3, p.325-330, 1981.

Loretz, C; Bern, H.A.; Foskett, J.K.; and Mainoya, J.R. The caudal neurosecretory system and osmoregulation in fish. In: Farner, D.S. and Lederis, K . eds., Neurosecretion - molecules, cells, systems. Plenum Press, New York, p.319328, 1981.

Loretz, C.A.; Freel, R.W. and Bern, H.A. Specificity of response of intestinal ion transport systems to a pair of natural peptide hormone analogs: somatostatin and urotensin II. Gen. Comp. Endocrinol., v.52, n.2, p.198-206, 1983.

Mainoya, J.R. Water and $\mathrm{NaCl}$ absorption by intestine of the tilapia Sarotherodon mossambicus adapted to fresh water or seawater and the possible role of prolactin and cortisol. J. Comp. Rhysiol., v.146, p.1-7, 1982

Mainoya, J.R. and Bern, H.A. Effects of teleost urotensins on intestinal absorption of water and sodium chloride in tilapia, Sarotherodon mossambicus, adapted to freshwater or seawater. Gen. Comp. Endocrinol., v.47, n.1, p.54-58, 1982.

Mainoya, J.R. and Bern, H.A. Influence of vasoactive intestinal peptide and urotensin II on the absorption of water and sodium chloride by the anterior intestine of the tilapia, Sarotherodon mossambicus. Zool. Sci. Tokyo, v.1, n.1, p.100-105, 1984.

Marshall, W.S. and Bern, H.A. Active chloride transport by the skin of a marine teleost (Gillichthys mirabilis) is stimulated by urotensin I and inhibited by urotensin II. Gen. Comp. Endocrinol., v.43, n.4, p.484-491, 1981.

Menin, E. Anátomo-histologia funcional comparativa do aparelho digestivo de seis teleostei (PISCES) de áqua doce. Ph.D. thesis, Instituto de Biociências, Universidade de Săo Paulo, Sấo Paulo, Brazil, 380 p, 1988.

Mimura, O. M. and Baldisserotto, B. Water and ions isotonic transport on gall bladder in Synbranchus marmoratus (TELEOSTEI): in vitro effects of urophysial homogenates. Abstract Xlth Int. Symp. Comp. Endocrinol., Malaga, Spain, 1989. 
Mimura, O.M.; Baldisserotto, B. and Menin, E. Transporte de água e íons no trato digestivo de Prochilodus marggravii (TELEOSTEI). Abstract Reun. An. FESBE, Rio de Janeiro, Brazil, 1987.

Nakamura, Y. "In vitro" absorption of inorganic phosphate and other electrolytes in the carp intestine. Comp. Biochem. Physiol., v.80A, n.1, p.17-20, 1985.

Paiva, M.P. Crescimento, alimentação e reprodução da traíra, Hoplias malabaricus (Bloch), no nordeste brasileiro. Ph.D. thesis, Instituto de Biociências, Universidade de São Paulo, São Paulo, Brazil, 32 p, 1974.

Rivas, R.J.; Nishioka, R.S. and Bern, H.A. "In vitro" effects of somatostatin and urotensin II on prolactin and growth hormone secretion in tilapia, Oreochromis mossambicus. Gen. Comp. Endocrinol., v.63, n.2, p.245-251, 1986.

Smith, M.W.; Ellory, J.C. and Lahlou, B. Sodium and chloride transport by the intestine of the european flounder, Platichthys flesus, adapted to fresh or sea water. Pfluegers Arch. Eur. J. Physiol., v.357, p.303-321, 1975. 